\title{
Defense responses in female gametophytes of Saccharina japonica (Phaeophyta) induced by flg22-derived peptides
}

\author{
Bojun $\mathrm{Lu}^{1} \cdot$ Dandan $\mathrm{Li}^{1} \cdot$ Rui Zhang $^{1} \cdot$ Limei Shuai $^{1} \cdot$ Birgit Schulze $^{2} \cdot$ \\ Peter G. Kroth ${ }^{2}$ - Dongmei Zhan ${ }^{3}$ - Gaoge Wang ${ }^{1}$
}

\begin{abstract}
Plants and algae can detect the presence of bacteria via sensing of proteins or peptides of bacterial origin. Flg22, a fragment of bacterial flagellin, is one of these peptides and has been shown to be an effective elicitor in both plants and algae. Here, we investigated the elicitor activity of flg22-derived peptides in the brown alga, Saccharina japonica. By monitoring luminoldependent fluorescence, we could observe that the release of $\mathrm{H}_{2} \mathrm{O}_{2}$ induced by flg22-derived peptides is maximal at $2 \mathrm{~h}$ after induction. The elicitor activity was depending on the length of the peptides in the order of flg22 $>$ flg $15>$ flg14. Cytological observations regarding the presence of reactive oxygen species (ROS) after induction were consistent with quantitative measurements of $\mathrm{H}_{2} \mathrm{O}_{2}$ generation using a $2^{\prime}, 7^{\prime}$-dichlorofluorescein diacetate (DCFH-DA) fluorescent probe. Addition of $1 \mu \mathrm{M}$ each of flg22 and flg15 was sufficient to inhibit growth of female gametophytes. Furthermore, the elicitor activity of C-terminally shortened flg15-derived peptides suggests that flg15 apparently is the
\end{abstract}

Bojun Lu and Dandan Li contributed equally to this work and should be considered joined first authors.

Dongmei Zhan

zdm1011@126.com

$\triangle$ Gaoge Wang

wgaoge@ouc.edu.cn

1 College of Marine Life Sciences, Ocean University of China, Yushan Road No. 5, Qingdao 266003, People's Republic of China

2 Plant Ecophysiology Fachbereich Biologie, Universitaet Konstanz, 78457 Konstanz, Germany

3 Marine Biology Institute of Shandong Province, Youyun Road No. 7, Qingdao 266104, People's Republic of China smallest peptide with elicitor activity. Amino acid position D43 at the N-terminus of a flagellin was demonstrated to be involved in the elicitor activity. Finally, $\mathrm{H}_{2} \mathrm{O}_{2}$ was localized in the plasma membranes of female gametophytes by an NADPH oxidase inhibitor and electron-dense deposits of cerium perhydroxide by transmission electron microscope.

Keywords Defense response $\cdot$ flg22 derivative peptides . Saccharina japonica $\cdot$ Reactive oxygen species

\section{Introduction}

Like higher plants, algae have developed effective defense mechanisms to protect themselves against various pathogens. It is widely accepted that the initiation of defense responses largely depends on the successful recognition of the pathogens based on specific elicitors produced by the pathogens (Potin et al. 2002; Jones and Takemoto 2004; Zipfel 2009). Elicitors can be divided into endogenous and exogenous elicitors based on their origins (Weinberger and Friedlander 2000; Küpper et al. 2001, Küpper et al. 2006; Cosse et al. 2007). Endogenous elicitors originate from structural compounds of host, such as the oligosaccharides, which are released from the host cell walls during enzymatic degradation of wall components caused by the pathogens, as it has been described in the brown alga Laminaria digitata (Küpper et al. 2001) and in the red alga Gracilaria conferta (Weinberger et al. 1999). Exogenous elicitors, in contrast, originate from the pathogens and may consist of lipopolysaccharide (LPS) fragments from their outer membranes (Graham et al. 1977) of chitin fragments, derivatives of the cell walls (Sharp et al. 1984; Baureithel et al. 1994), or oligopeptides secreted by the bacteria (Wei et al. 1992; Nürnberger et al. 1994).

Flagellin/flg22 is one of the best-studied exogenous elicitors, representing a pathogen-associated molecular pattern (PAMP) 
that can induce defense responses in higher plants (Medzhitov and Janeway 2002; Nürnberger et al. 2004; Sun et al. 2013; Koller and Bent 2014). Felix et al. (1999) were the first to report that a 22-amino-acid peptide called flg22, which corresponds to the highly conserved $\mathrm{N}$-terminal region of flagellin, can induce immunity reaction in various plants such as tomato (Solanum lycopersicum), potato (Solanum tuberosum), tobacco (Nicotiana tabacum), and Arabidopsis thaliana. Defense responses induced by flg22 include alkalinization of the extracellular medium, generation of reactive oxygen species (ROS), expression of pathogenesis-related (PR) genes, callose deposition, and growth inhibition in A. thaliana and tomato (Felix et al. 1999; GómezGómez et al. 1999). Furthermore, the aspartic acid (D) at position 43 of the flagellin was identified as an active site for the elicitor activity. Replacing this reside by valine (V) and alanine (A) in flg22 of Pseudomonas syringae pv. tabaci 6605 (flg22 $2_{p t a} \mathrm{D} 43 \mathrm{~V}$ and flg22 $2_{p t a} \mathrm{D} 43 \mathrm{~A}$ ), abolished the elicitor activity (Naito et al. 2008). So far, it has been shown that flg15 is the smallest elicitor in tomato, having a much weaker activity than flg22 in A. thaliana (Felix et al. 1999; Meindl et al. 2000; Chinchilla et al. 2006). Shorter peptides have an even lower elicitor activity in various plants (Felix et al. 1999; Bauer et al. 2001). So far, flagellin and the respective recognition receptor FLAGELLINE SENSING 2 (FLS2) in $A$. thaliana are the best studied model for elicitor recognition in plants (Boller and Felix 2009). Although structure-activity relationships of flg22 have been studied over a long term, it is until 2013 to reveal the exact binding site of flg22 within the leucine-rich repeat (LRR) domains of FLS2 and BAK1 by crystallography (Sun et al. 2013).

The first indication of PAMP-induced defense responses in algae was described for the red alga Chondrus crispus which can be induced by its pathogen Acrochaete operculata. The cell-free extract of $A$. operculata triggered an oxidative burst in C. crispus (Bouarab et al. 1999). Additionally, liposaccharides and lipoteichoic acids isolated from the cell envelope of bacteria were found to modify gene expression of C. crispus, indicating that PAMP elicitors are present in these cell-free extracts (Weinberger 2007). Similarly, the red alga $G$. conferta reacts on the presence oligosaccharides with the production of ROS, which controls the growth of epiphytic bacteria (Weinberger and Friedlander 2000). LPS extracted from the Gram-negative bacterium Salmonella arbortus equi was shown to be an efficient elicitor triggering an oxidative burst in L. digitata (Küpper et al. 2006). Also unicellular algae, such as diatoms, may react on the presence of bacteria not only with hypersensitive cell death (Canter and Jaworski 1979), but also with the release of defensive enzymes. For example, the diatom Chaetoceros didymus releases proteases which confer resistance to the lytic bacterium Kordia algicida (Paul et al. 2013). In striking contrast to the intensive investigations of PAMPs and induced defense responses in higher plants, knowledge on respective elicitors and immunity mechanisms in marine algae is still very poor. Recently,
Wang et al. $(2012,2013)$ found that flg22 can induce oxidative bursts and hypersensitive responses (HR) in both female gametophytes and sporophytes of Saccharina japonica, indicating that algae and plants may share similar mechanisms for recognizing pathogens.

Typically, early defense responses following the recognition of an elicitor include oxidative bursts, such as the generation of ROS including $\mathrm{O}_{2}, \mathrm{H}_{2} \mathrm{O}_{2}$, and $\cdot \mathrm{OH}$. Plasma membranes and cell walls have been identified as the source of $\mathrm{H}_{2} \mathrm{O}_{2}$ during PAMP-triggered immunity responses. A membrane-located, diphenyleneiodonium chloride (DPI)-sensitive NADPH oxidase can be assembled in the plasma membranes after receptor-based recognition of pathogens or elicitors, catalyzing an electron transfer from NADPH to $\mathrm{O}_{2}$ resulting in $\mathrm{O}_{2} \cdot$ and $\mathrm{H}_{2} \mathrm{O}_{2}$ (Cosse et al. 2007). While, cell wall-located $\mathrm{pH}-$ dependent and salicylhydroxamic acid (SHAM)- and sodium azide $\left(\mathrm{NaN}_{3}\right)$-sensitive peroxidases can be activated due to an increase of $\mathrm{pH}$ caused by the cationic efflux after pathogens invading plants (Bestwick et al. 1997; Song and She 2010). These enzymes reduce $\mathrm{O}_{2}$ rapidly to $\mathrm{O}_{2} \cdot$ and $\mathrm{H}_{2} \mathrm{O}_{2}$ (Song and She 2010). The sources of $\mathrm{H}_{2} \mathrm{O}_{2}$ can be distinguished by pharmacological investigations and electron microscopy, demonstrating the release of $\mathrm{H}_{2} \mathrm{O}_{2}$ in the marine red algae G. conferta and Gracilaria chilensis (Weinberger et al. 2005). However, so far, there is no report yet on the source of $\mathrm{H}_{2} \mathrm{O}_{2}$ induced by flg22 in gametophytes of the very distantly related brown alga $S$. japonica.

According to our previous study, flg22 is an effective elicitor for S. japonica (Wang et al. 2012; Wang et al. 2013); thus, the question raised here is whether flg22-derived peptides can also trigger defense responses in S. japonica. Therefore, we investigated the elicitor activity of flg22-derived peptides, as well as the active site of flg22 on female gametophytes of $S$. japonica. We also studied the subcellular origin of $\mathrm{H}_{2} \mathrm{O}_{2}$ induced by flg 22 .

\section{Materials and methods}

Female gametophytes of Saccharina japonica were cultivated as a suspension culture. The gametophytes were grown in illuminated incubators (GXZ-280A, Jiangnan, China) at $10{ }^{\circ} \mathrm{C}$ with a $12: 12-\mathrm{h}(\mathrm{L} / \mathrm{D})$ photoperiod at $25 \mu \mathrm{mol}$ photons $\mathrm{m}^{2} \mathrm{~s}^{1}$. The culture medium consisted of sterilized seawater provided with $0.2 \mathrm{mM} \mathrm{KNO}_{3}$ and $0.02 \mathrm{mM} \mathrm{KH}_{2} \mathrm{PO}_{4}$ and was replaced once a week.

\section{Flg22-derived peptides}

The peptides flg22 (QRLSTGSRINSAKDDAAGLQIA), flg22D43A (QRLSTGSRINSAKADAAGLQIA), flg15 (RINSAKDDAAGLQIA), flg14 (INSAKDDAAGLQIA), flg $15-\Delta 1$ (RIN S A D D A GLQI), flg $15-\Delta 2$ 
(RINSAKDDAAGLQ), flg15- $\Delta 3$ (RINSAKDDAAGL), flg15- $\Delta 4$ (RINSAKDDAAG), flg15- $\Delta 5$ (RINSAKDDAA), flg15- $\Delta 6$ (RINSAKDDA), flg $15-\Delta 7$ (RINSAKDD), and flg15- $\Delta 8$ (RINSAKD) were synthesized by Sangon Biotech (Shanghai) Co. Ltd. Peptides were dissolved to $4 \mathrm{mM}$ in sterilized seawater and diluted in a solution containing $0.1 \%$ bovine serum albumin (BSA).

\section{Incubation experiments}

The density of the fresh female gametophytes was generally $5 \mathrm{mg} \mathrm{mL}{ }^{1}$. In order to facilitate the following experiments, the female gametophytes were broken into pieces in a crusher (JYD-P11S81, Joyoung, China) for $20 \mathrm{~s}$ then subcultured for 3-5 days at $10{ }^{\circ} \mathrm{C}$ with a $12: 12-\mathrm{h}$ (L/D) photoperiod at $25 \mu \mathrm{mol}$ photons $\mathrm{m}^{2} \mathrm{~s}{ }^{1}$. Short-time incubation with different peptide concentrations was performed in an illumination incubator under the subculture conditions described above. Control experiments of sterilized seawater or $0.1 \%$ BSA in sterilized seawater were employed. All experiments had at least three replicates.

\section{$\mathrm{H}_{2} \mathrm{O}_{2}$ detection and quantification}

$\mathrm{H}_{2} \mathrm{O}_{2}$ was monitored by measuring luminol-dependent luminescence ascribable to ferricyanide-catalyzed oxidation according to a previous method described by Takai et al. (2008) and Wang et al. (2013). Twenty microliters of incubated gametophytes was mixed with $150 \mu \mathrm{L}$ of $10 \mathrm{mM}$ potassium phosphate buffer ( $\mathrm{pH} 7.8$ ), $20 \mu \mathrm{L}$ of $14 \mathrm{mM}$ potassium ferricyanide, and $10 \mu \mathrm{L}$ of $1.1 \mathrm{mM}$ luminol solution; then, the samples were placed in a luminometer (GloMax 20/20, Promega, USA) and analyzed for chemiluminescence immediately.

\section{Cytological detection of the ROS}

The gametophytes were incubated for $2 \mathrm{~h}$ with different concentrations of the different peptides and then were washed with sterilized seawater twice to remove the peptides, followed by re-suspension for $5 \mathrm{~min}$ in sterilized seawater containing $50 \mu \mathrm{M} \mathrm{2}$ 2,7'-dichlorofluorescein diacetate (DCFH-DA, Sigma, USA). Subsequently, the gametophytes were rinsed with sterilized seawater twice to remove the residual DCFHDA, and they were placed onto glass slides for observations by using a fluorescence microscope (BX51, Olympus, Japan) at an excitation wavelength of $380-490 \mathrm{~nm}$.

\section{Growth inhibition assay}

One milliliter of the female gametophytes was added to $100 \mathrm{~mL}$ sterilized seawater containing $1 \mu \mathrm{M}$ of flg22, flg15, flg14, and flg22D43A, respectively. Controls were sterilized seawater and $0.1 \%$ BSA in sterilized seawater. Gametophytes were grown at $10{ }^{\circ} \mathrm{C}$ with a 24 -h photoperiod at $50 \mu \mathrm{mol}$ photons $\mathrm{m}^{2} \mathrm{~s}^{1}$. Sterilized seawater medium was provided with $0.2 \mathrm{mM} \mathrm{KNO}_{3}, 0.02 \mathrm{mM} \mathrm{KH}_{2} \mathrm{PO}_{4}$, and $1 \mu \mathrm{M}$ of the four respective peptides and refreshed every week. The gametophytes were briefly blotted dry, and the fresh weight was measured after 40 days.

\section{Subcellular localization of $\mathrm{H}_{2} \mathrm{O}_{2}$}

The cytochemical method for localization of $\mathrm{H}_{2} \mathrm{O}_{2}$ was based on the generation of insoluble cerium peroxide according to Bestwick et al. (1997). After inoculation with flg22 for $2 \mathrm{~h}$, the female gametophytes were incubated in culture medium containing $5 \mathrm{mM}$ cerium chloride and $50 \mathrm{mM}$ 3-(morpholino) propanesulfonic acid (Mops) buffer ( $\mathrm{pH} 7.2$ ) for $1 \mathrm{~h}$. The treated gametophytes were then fixed in $3 \%(v / v)$ glutaraldehyde in $0.1 \mathrm{M}$ sodium phosphate buffer (pH 7.2) at $4{ }^{\circ} \mathrm{C}$ for $6 \mathrm{~h}$ and post-fixed in $2 \%$ osmium tetroxide in the same buffer. Samples were dehydrated in a graded ethanol series and embedded in Araldite. The control was treated with sterilized seawater, while the positive control was treated with $5 \mathrm{mM} \mathrm{H}_{2} \mathrm{O}_{2}$ for $10 \mathrm{~min}$. All the experiments were designed three replicates. According to our previous studies, $0.1 \%$ BSA has no effect on the production of $\mathrm{H}_{2} \mathrm{O}_{2}$; therefore, control experiments with $0.1 \%$ BSA were not included in this and the following experiments.

\section{Effects of DPI, SHAM, and $\mathrm{NaN}_{3}$ on $\mathrm{H}_{2} \mathrm{O}_{2}$ accumulation}

Fragmented filamentous gametophytes at a density of $5 \mathrm{mg} \mathrm{mL}{ }^{1}$ were inoculated with $200 \mu \mathrm{M}$ flg22 and $60 \mu \mathrm{M}$ DPI, $50 \mu \mathrm{M}$ SHAM, or $50 \mu \mathrm{M} \mathrm{NaN}_{3}$ for $2 \mathrm{~h}$. For two control experiments, one algal suspension was treated with sterilized seawater for $2 \mathrm{~h}$; the other was algal suspension treated with $200 \mu \mathrm{M}$ flg2 2 for $2 \mathrm{~h}$. All experiments had at least three replicates.

\section{Results}

Quantitative detection of $\mathrm{H}_{2} \mathrm{O}_{2}$ in female gametophytes induced by flg22 and its derived peptides

The release of $\mathrm{H}_{2} \mathrm{O}_{2}$ was investigated by using a luminoldependent assay. Within the range of $0-200 \mu \mathrm{M}$ of flagellin peptides, $\mathrm{H}_{2} \mathrm{O}_{2}$ release was related to the concentrations of flg22 and flg15, respectively (Fig. 1). The response was saturated at $260 \mu \mathrm{M}$. The concentration of flg22 required to induce half maximal activity $\left(\mathrm{EC}_{50}\right)$ is $90 \mu \mathrm{M}$, while the $\mathrm{EC}_{50}$ value of flg15 is $110 \mu \mathrm{M}$ (Fig. 1). Moreover, the concentrations required to induce the same $\mathrm{H}_{2} \mathrm{O}_{2}$ production were slightly lower for flg22 compared to flg15; however, there was no 


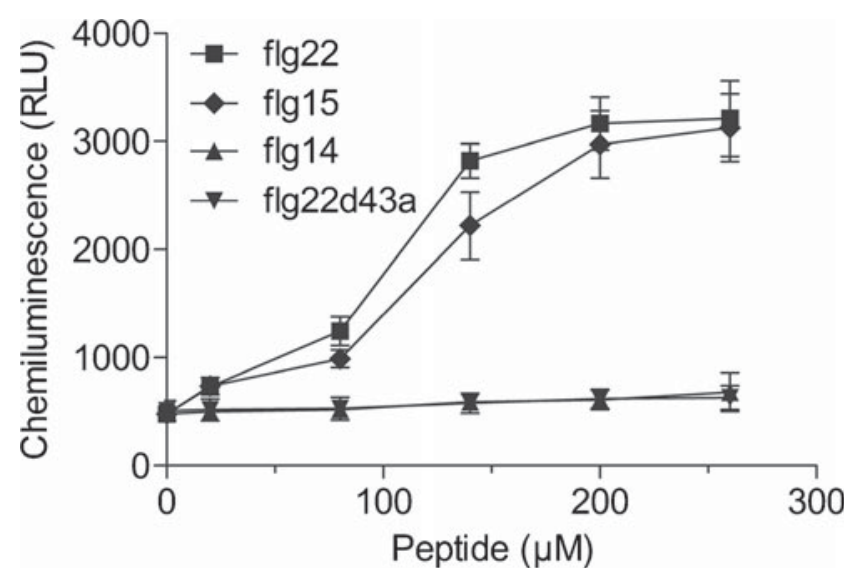

Fig. 1 Release of $\mathrm{H}_{2} \mathrm{O}_{2}$ in female gametophytes of $S$. japonica by different concentrations of flg22, flg15, flg14, and flg22D43A after $2 \mathrm{~h}$ of incubation. Values are means $\pm \mathrm{SD}(n=6)$

significant difference in elicitor activity induction between flg22 and flg15, while flg14 and flg22D43A did not show any elicitor activity (Fig. 1). For flg14, the production of $\mathrm{H}_{2} \mathrm{O}_{2}$ increased in a concentration-dependent manner within the range of 400 to $1000 \mu \mathrm{M}$ and the $\mathrm{EC}_{50}$ was about $720 \mu \mathrm{M}$ (Fig. S1). There was no $\mathrm{H}_{2} \mathrm{O}_{2}$ detected in female gametophytes induced by flg22D43A (Fig. S1), which implied that aspartic acid at position 43 also played a crucial role for flg22 as an effective elicitor in $S$. japonica.

Figure 2 shows the release of $\mathrm{H}_{2} \mathrm{O}_{2}$ by female gametophytes of $S$. japonica induced by flg22, flg15, flg14, and flg22D43A at concentration of $90 \mu \mathrm{M}$. The production of $\mathrm{H}_{2} \mathrm{O}_{2}$ induced by flg22 and flg15 increased and reached maximum values after $2 \mathrm{~h}$, respectively (Fig. 2). After that time, the $\mathrm{H}_{2} \mathrm{O}_{2}$ production declined gradually and returned to the initial level after $6 \mathrm{~h}$ (Fig. 2). No measurable $\mathrm{H}_{2} \mathrm{O}_{2}$ was detected after induction by flg14 and flg22D43A within 6 h (Fig. 2).

\section{Cytological detection of ROS in female gametophytes induced by flg22, flg15, flg14, and flg22D43A}

The fluorescent probe DCFH-DA was utilized for cytological detection of ROS via fluorescence microscopy in the female gametophytes of $S$. japonica after induction by flg22, flg15, flg14, and flg22D43A. Compared to the controls (Fig. 3a, b), weak green DCF fluorescence was observed in female gametophytes after induction with flg 22 and flg 15 at the concentrations of $20 \mu \mathrm{M}$. The fluorescence intensity increased with the increasing concentrations in the range of 20-200 $\mu \mathrm{M}$. ROSbased fluorescence induced by flg 22 and flg 15 at a concentration of $80 \mu \mathrm{M}$ is shown in Fig. 3c, d. In flg14-induced female gametophytes, the fluorescence was observed at a minimum concentration of $600 \mu \mathrm{M}$ (Fig. 3e) and the fluorescent intensity increased within the range from 600 to $1000 \mu \mathrm{M}$. For flg22D43A, no ROS was detected even at a concentration of $1000 \mu \mathrm{M}$ (Fig. 3f). The cytological observations were consistent with the results of luminol fluorescence detection.

\section{Growth inhibition of female gametophytes by flg22 and flg22-derived peptides}

After culturing the female gametophytes of $S$. japonica in the presence of flg22, flg15, flg14, and flg22D43A for 40 days, both flg22 and flg15 significantly induced growth inhibition of the algae at a concentration of $1 \mu \mathrm{M}$. The fresh weights of flg22- and flg15-challenged female gametophytes were less than one half of the control (Fig. 4). Flg14 resulted only in a weak inhibition of growth (Fig. 4), while flg22D43A did not affect growth of S. japonica.

\section{Quantitative detection of $\mathrm{H}_{2} \mathrm{O}_{2}$ in female gametophytes induced by flg15 and flg15-derived peptides}

At low peptide concentrations $(20-200 \mu \mathrm{M})$, all of the flg15derived peptides failed to induce the release of $\mathrm{H}_{2} \mathrm{O}_{2}$. At higher concentrations $(200-1000 \mu \mathrm{M})$, we found that $\mathrm{H}_{2} \mathrm{O}_{2}$ production induced by flg $15-\Delta 1$, flg $15-\Delta 2$, and flg $15-\Delta 3$ increased with the increasing concentrations, reaching similar $\mathrm{H}_{2} \mathrm{O}_{2}$ production as with flg15 (Fig. 5). There was no significant difference in elicitor activities among the peptides of flg15- $\Delta 1$, flg15- $\Delta 2$, and flg15- $\Delta 3$ (Fig. 5). The release of $\mathrm{H}_{2} \mathrm{O}_{2}$ induced by flg $15-\Delta 4$ showed a similar trend to that of flg15- $\Delta 1$, flg $15-\Delta 2$, and flg $15-\Delta 3$ within a concentration
Fig. 2 Release of $\mathrm{H}_{2} \mathrm{O}_{2}$ in female gametophytes of $S$. japonica induced by $90 \mu \mathrm{M}$ flg22, flg15, flg14, and flg22D43A at different time courses. Values are means \pm $\operatorname{SD}(n=6)$.

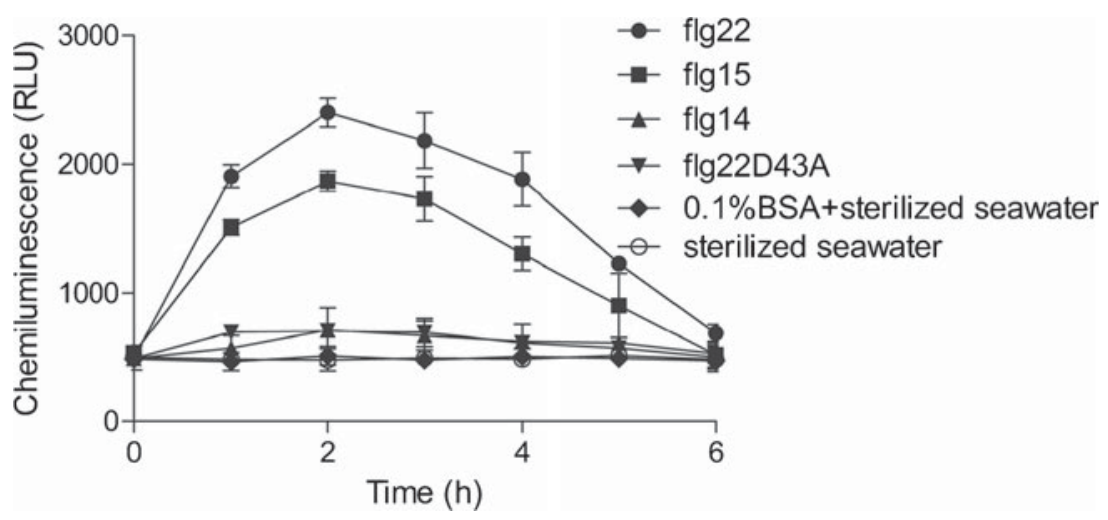




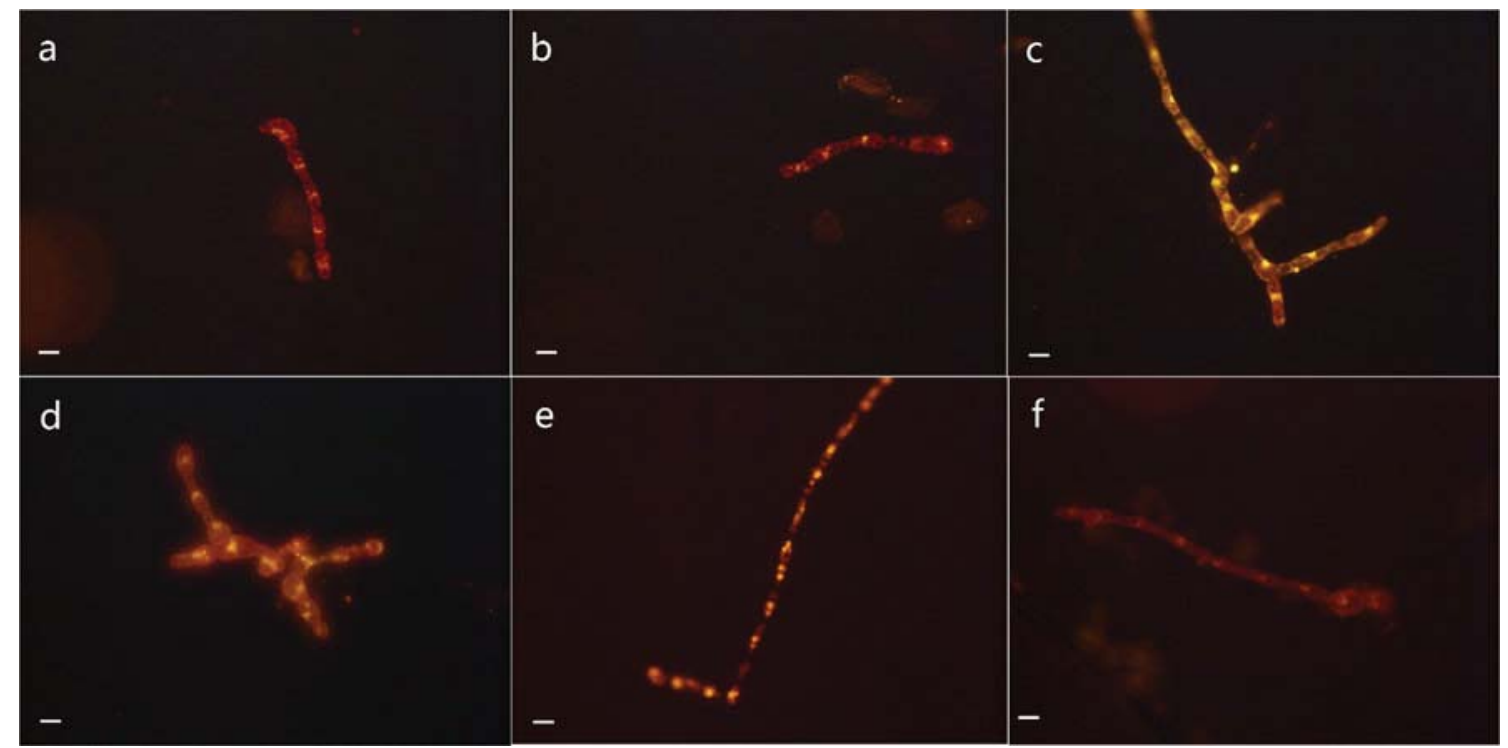

Fig. 3 Fluorescence images of ROS production in female gametophytes of $S$. japonica after $2 \mathrm{~h}$ of incubation and induced by flg22 derived peptides. a Control experiment treated with sterilized seawater. b Control experiment treated with $0.1 \% \mathrm{BSA}+$ sterilized seawater. c

range of $200-1000 \mu \mathrm{M}$; however, flg $15-\Delta 4$ showed a comparatively lower elicitor activity (Fig. 5). No production of $\mathrm{H}_{2} \mathrm{O}_{2}$ was detected after incubation with flg15- $\Delta 5$, flg15- $\Delta 6$, flg15- $\Delta 7$, and flg15- $\Delta 8$ (Fig. 5). These findings indicate that peptides lacking five or more residues at the $\mathrm{C}$ terminus (from flg $15-\Delta 5$ to flg $15-\Delta 8$ ) might not be detected by $S$. japonica, However, flg15- $\Delta 5$, flg $15-\Delta 6$, and flg $15-\Delta 7$, but not flg15- $\Delta 8$, did suppress the release of $\mathrm{H}_{2} \mathrm{O}_{2}$ induced by

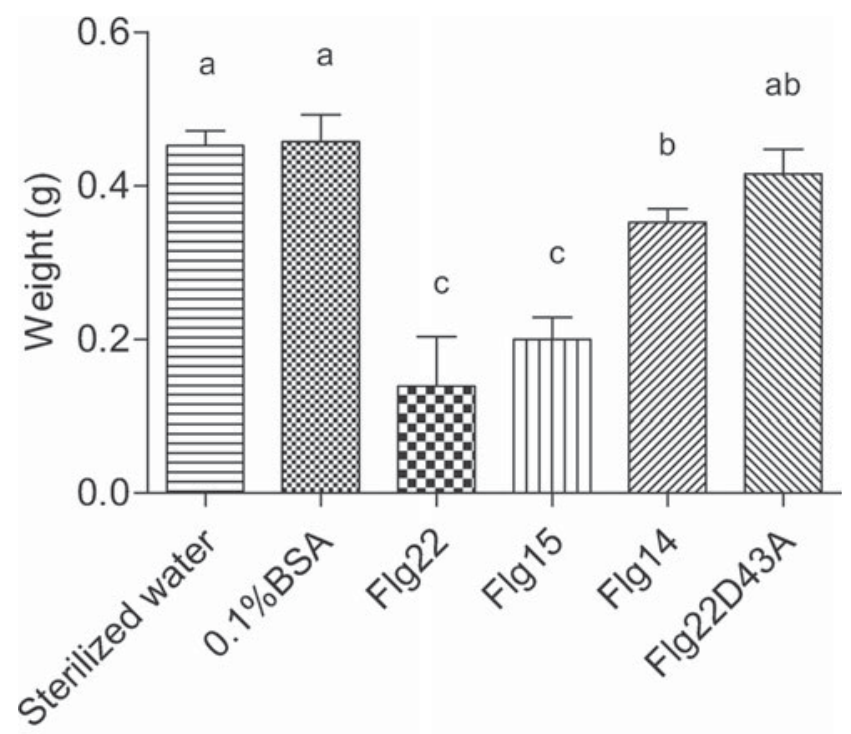

\section{Peptides}

Fig. 4 Growth inhibition of cultured clones of female gametophytes of $S$. japonica by four various peptides. Values are means \pm SD $(n=3)$. Statistically significant differences (ANOVA, Tukey) are indicated by lowercase letter superscripts $(P<0.05)$ flg22, $80 \mu \mathrm{M}$. d flg15, $80 \mu \mathrm{M}$. e flg14, $600 \mu \mathrm{M}$. f flg22D43A, $1000 \mu \mathrm{M}$. The green fluorescent spots indicate ROS production in cells of female gametophytes. Bars $10 \mu \mathrm{m}$

flg15, respectively (Fig. 6), indicating an antagonistic effect of these three peptides.

\section{Cytological detection of ROS in the female gametophytes induced by flg15-derived peptides}

Cytological detection of ROS using DCFH-DA showed that the elicitor activity of all flg15-derived peptides declined with a reduced length. However, a ROS production similar to flg 15 induction can be induced by flg $15-\Delta 1$, flg $15-\Delta 2$, and flg $15-\Delta 3$ at higher concentrations $(1000 \mu \mathrm{M})$ (Figs. S2g, $\mathrm{S} 3 \mathrm{~g}$, and $\mathrm{S} 4 \mathrm{~g})$. Interestingly, we could not detect any significant differences in elicitor activity among these three peptides. While for ROS production, flg $15-\Delta 4$ had to be applied in very high concentrations (Fig. S5). We could not detect DCF fluorescence in female gametophytes when challenged with flg15- $\Delta 5$, flg15- $\Delta 6$, flg15- $\Delta 7$, and flg15- $\Delta 8$ (Fig. S6). The cytological observations were consistent with the results of luminol fluorescence detection.

\section{Pharmacological results in S. japonica challenged by flg22}

The release of $\mathrm{H}_{2} \mathrm{O}_{2}$ induced by flg22 was approximately twice that of the seawater control (Fig. 7). DPI, a specific inhibitor of the NADPH oxidase, strongly inhibited the release of $\mathrm{H}_{2} \mathrm{O}_{2}$ in flg22-induced $S$. japonica at a concentration of $60 \mu \mathrm{M}$ (Fig. 7). $\mathrm{H}_{2} \mathrm{O}_{2}$ production was increased after inhibition of the peroxidase activity by addition of $50 \mu \mathrm{M}$ of either $\mathrm{NaN}_{3}$ or SHAM (Fig. 7). These results imply that in $S$. japonica, $\mathrm{H}_{2} \mathrm{O}_{2}$ generation is by a membrane-located NADPH oxidase, but not by cell wall-bound peroxidases. 
Fig. 5 Release of $\mathrm{H}_{2} \mathrm{O}_{2}$ in female gametophytes of $S$. japonica induced by various concentrations of flg 15 and flg15 derived peptides. Values are means $\pm \mathrm{SD}(n=6)$

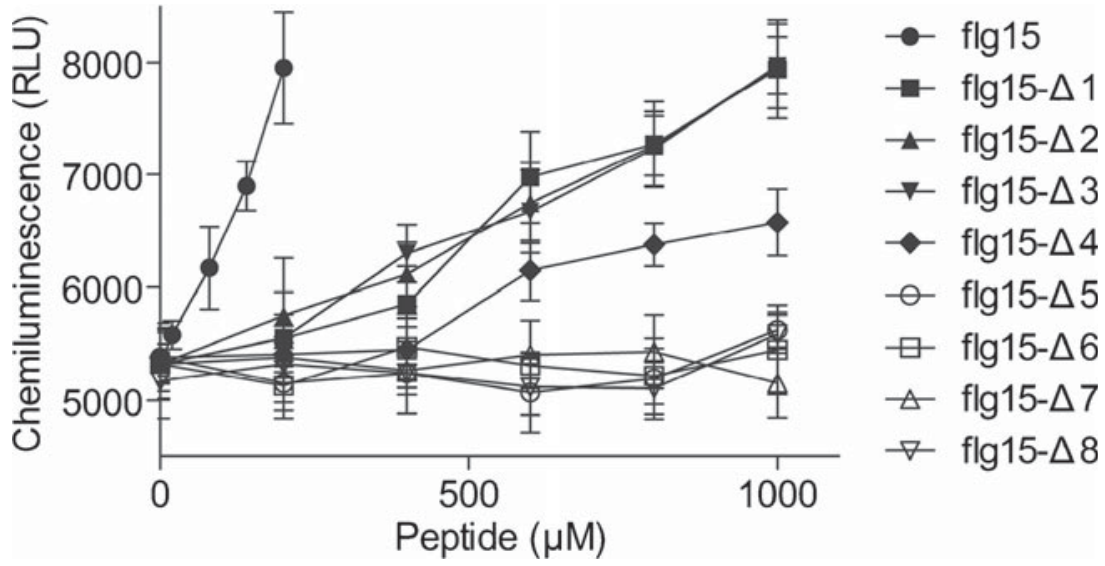

\section{Subcellular localization of $\mathrm{H}_{2} \mathrm{O}_{2}$ in $S$. japonica challenged by flg22}

In order to localize $\mathrm{H}_{2} \mathrm{O}_{2}$ production intracellularly, $\mathrm{H}_{2} \mathrm{O}_{2}$ dependent cerium peroxide precipitates were observed by electron microscopy in the cell wall after incubation of female gametophytes of $S$. japonica with both cerium chloride and $\mathrm{H}_{2} \mathrm{O}_{2}$ (Fig. 8b). Visible electron-dense precipitates appeared in the plasma membranes (Fig. 8c-e) when female gametophytes were incubated in the presence of both cerium chloride and flg22. Precipitates of cerium peroxide were not observed in the control with sterilized seawater (Fig. 8a).

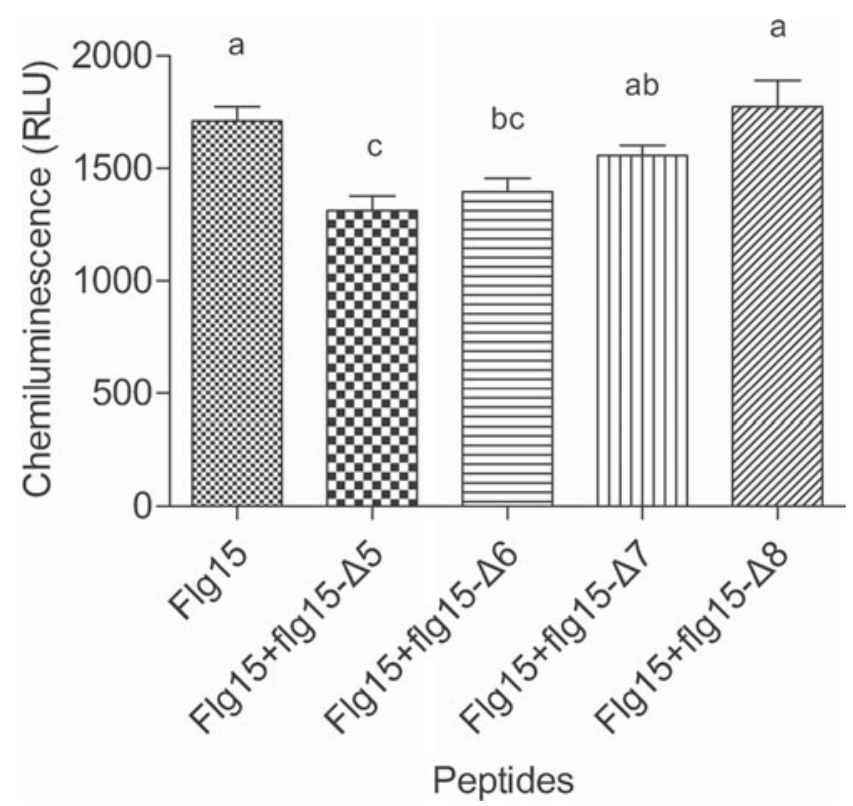

Fig. 6 Release of $\mathrm{H}_{2} \mathrm{O}_{2}$ in female gametophytes of $S$. japonica co incubated with flg15 and flg 15 derived peptides at a concentration of $90 \mu \mathrm{M}$, showing antagonistic elicitor effects of flg15 $\Delta 5$, flg15 $\Delta 6$, and flg15 $\Delta 7$. Values are means \pm SD $(n=6)$. Statistically significant differences (ANOVA, Tukey) are indicated by lowercase letter superscripts $(P<0.05)$

\section{Discussion}

In this study, we investigated the structure-elicitor activity of flg22- and flg15-derived peptides in female $S$. japonica gametophytes by using a luminol-dependent assay and a DCFHDA fluorescent probe. Because flg22 has been described as an effective elicitor in both female gametophytes (Wang et al. 2013) and sporophytes of $S$. japonica (Wang et al. 2012), this paper focuses on the structure-elicitor relationship of flg22and flg15-derived peptides. The relation between the structure and the elicitor activity of flg22- and flg15-derived peptides has been intensively studied in various plants, especially in tomato and $A$. thaliana. The elicitor activity of flg22, flg15, and flg14 in tomato and in $A$. thaliana shows some similarity but also exhibits respective characteristic differences. While flg22 shows the full elicitor activity in both species, flg15 exhibits a reduced elicitor activity in tomato and almost no

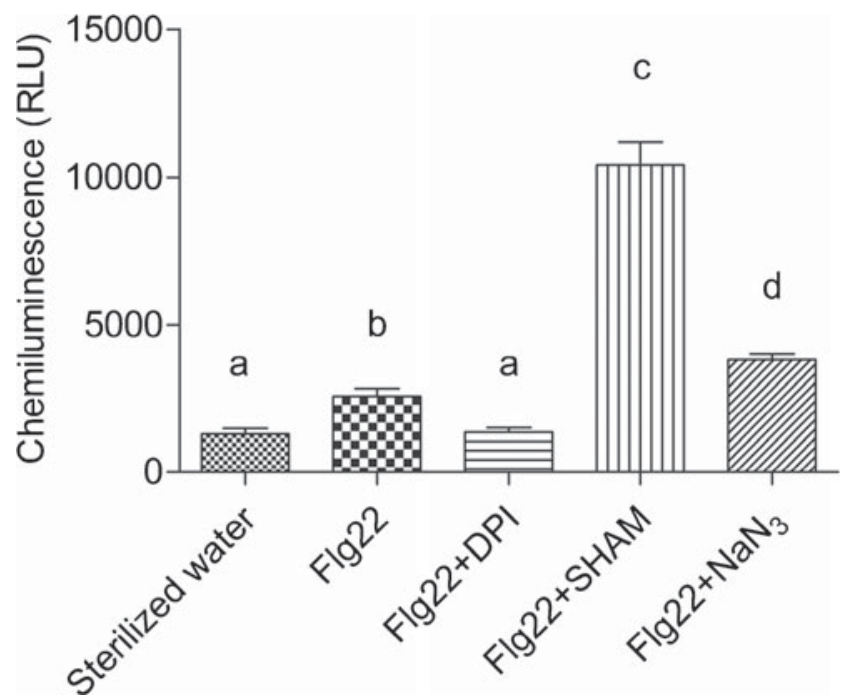

Fig. 7 Release of $\mathrm{H}_{2} \mathrm{O}_{2}$ in flg22 induced female gametophytes of $S$. japonica by DPI, SHAM, and $\mathrm{NaN}_{3}$. The concentrations of DPI, SHAM, and $\mathrm{NaN}_{3}$ were 60,50 , and $50 \mu \mathrm{M}$, respectively. Values are means \pm SD $(n=3)$. Statistically significant differences (ANOVA, Tukey) are indicated by lowercase letter superscripts $(P<0.05)$ 
Fig. 8 Subcellular localization of $\mathrm{H}_{2} \mathrm{O}_{2}$ in $\mathrm{S}$. japonica by electron microscopy. a Cell of $S$. japonica (control). b Cell of $S$. japonica incubated in $5 \mathrm{mM} \mathrm{H}_{2} \mathrm{O}_{2}$ for $10 \mathrm{~min}$ (positive control). c e Cells of $S$. japonica incubated with flg22 for $2 \mathrm{~h}$. Dense cerium peroxide precipitates (arrows) were observed on cell walls (b) and plasma membranes (c e). $C W$ cell wall, $P M$ plasma membranes. Bars $=1 \mu \mathrm{m}$. GraphPad Prism was used to create the artwork

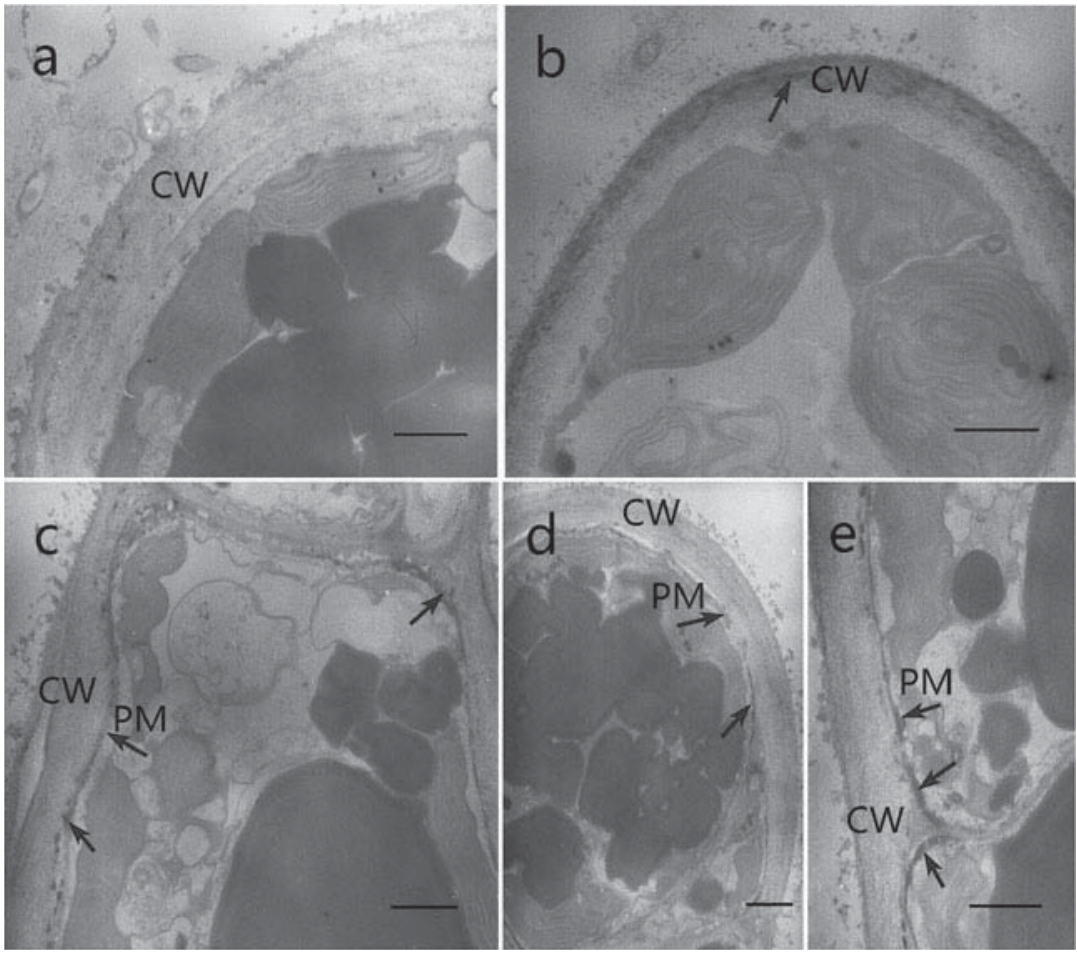

elicitor activity in A. thaliana (Felix et al. 1999). This indicates that $A$. thaliana recognizes peptides with longer domain lengths than tomato plants (Bauer et al. 2001). In our study on the brown alga $S$. japonica, the $\mathrm{EC}_{50}$ values for flg22, flg15, and flg 14 were determined to be 90,110 , and $720 \mu \mathrm{M}$, respectively. The elicitor activity of the peptides was reduced with shorter lengths (flg22 > flg15 > flg14), which is similar to respective studies in tomato, indicating a similar mechanism (Felix et al. 1999). Felix et al. found that the concentrations required for half-maximal alkalinization of flg22, flg15, and flg 14 were $0.03,0.1$, and $1 \mathrm{nM}$, respectively. For the Cterminally truncated peptides, the elicitor activity of flg $15-\Delta 2$ and flg15- $\Delta 3$ decreased significantly in tomato (Felix et al. 1999). Peptides lacking four to eight amino acid residues at the C-terminus of flg 15 , such as flg15- $\Delta 4$, flg $15-\Delta 5$, flg $15-\Delta 6$, flg $15-\Delta 7$, and flg $15-\Delta 8$, have no elicitor activity but do have antagonistic effects on elicited defense response, while flg15- $\Delta 9$ is completely inactive in tomato (Felix et al. 1999). While for $A$. thaliana, the flg $15-\Delta 2$ acts as a weak antagonist (Bauer et al. 2001). Our results showed that the elicitor activity of flg $15-\Delta 1$, flg $15-\Delta 2$, and flg $15-\Delta 3$ decreased significantly in $S$. japonica compared to flg 15 and the activity was reduced stronger for flg15- $\Delta 4$. Flg15- $\Delta 5$, flg15- $\Delta 6$, flg15- $\Delta 7$, and flg $15-\Delta 8$ showed no elicitor activity. Interestingly, flg $15-\Delta 5$ to flg $15-\Delta 7$ had no elicitor activity but acted as competitive and specific antagonists of flg 15 in $S$. japonica, which is similar to the flg $15-\Delta 4$ to flg $15-\Delta 7$ peptides in tomato. This may be explained by competition between the antagonistic peptides and the elicitor-active peptides for the same binding site on the hypothetical flagellin receptor. Regarding receptor activation by flg15, Felix et al. (1999) proposed a mechanism involving the binding of the Nterminal part and the activation of signaling by the $\mathrm{C}$-terminal part as two functionally separate steps. This kind of mechanism for recognizing elicitors meanwhile has been found in plant cells, in particular for the yeast-derived glycopeptide (Basse et al. 1992), the wound hormone system (Meindl et al. 1998), and flg22 (Meindl et al. 2000). Therefore, according to our results, structure-elicitor activity of flg22- and flg15-derived peptides is more similar to the tomato response system.

The elicitation-active site of flagellin/flg22 was intensively investigated in A. thaliana. Sun et al. (2006) identified defense-eliciting structural elements by dissecting the entire flagellin protein of Xanthomonas campestris pv campestris (Xcc). Domain replacement and site-directed mutagenesis together showed that the amino acid at position 43 is crucial for the elicitation activity. Replacements of D43 inevitably caused the loss of elicitation ability of Xcc B305 flagellin, and importantly, the reciprocal V43D substitution converted non-eliciting Xcc B186 flagellin to an eliciting flagellin. D43 also plays an essential role in A. thaliana. Naito et al. (2008) found that the replacement of D43 with valine (V) and alanine (A) in P. syringae pv. tabaci flagellin and its flg22 resulted in the reduced abilities of flagellins to induce cell death and growth inhibition in A. thaliana, whereas the abilities of flg22 D43V and flg22 D43A were abolished. These results indicate that D43 is important for elicitor activity in P. syringae pv. tabaci. Here, we observed a similar phenomenon in S. japonica. Even at a concentration of $1000 \mu \mathrm{M}$, flg22D43A failed to induce the production 
of $\mathrm{H}_{2} \mathrm{O}_{2}$, implying that D43 is also the elicitation-active site in $S$. japonica. Combining our data of the elicitor activity of flg22 and flg15 as well as functional site of D43, it appears that $S$. japonica may possess similar flagellin/flg22 recognition systems and signal transduction pathways as found in tomato.

Growth-inhibiting effects of flg22 were first reported by Gómez-Gómez et al. (1999) in A. thaliana. They found that $0.01 \mu \mathrm{M}$ of flg22 can inhibit the growth of $A$. thaliana seedlings after 7 days. This growth inhibition was positively correlated with strength of the elicitor activity. Growth inhibition phenomena have become typical features of defense responses of $A$. thaliana. Female gametophytes of $S$. japonica also show growth inhibition effects induced both by flg 22 and by flg 15 , correlating with the elicitor activities. The elicitor activities of flg22, flg15, and flg14 decline in this order, and the growthinhibiting effects followed the same pattern. We thus conclude that growth inhibition is a typical feature of the defense response in $S$. japonica.

In our experiments, the production of $\mathrm{H}_{2} \mathrm{O}_{2}$ was inhibited by DPI at a concentration of $60 \mu \mathrm{M}$ (Fig. 7), which was about 200 times higher than the concentration required for G. conferta (Weinberger et al. 2005). The difference between $S$. japonica and $G$. conferta might be caused by the thicker cell walls of S. japonica. Similar to G. conferta (Weinberger et al. 2005), SHAM, and $\mathrm{NaN}_{3}$, inhibitors of peroxidases (O'Brien et al. 2000; Weinberger et al. 2005), could increase the production of $\mathrm{H}_{2} \mathrm{O}_{2}$ in $\mathrm{S}$. japonica (Fig. 7). Peroxidases have at least two functions: they reduce $\mathrm{O}_{2}$ into $\mathrm{O}_{2} \cdot$ and $\mathrm{H}_{2} \mathrm{O}_{2}$, and they can scavenge $\mathrm{H}_{2} \mathrm{O}_{2}$. Therefore, in our study, the increase of $\mathrm{H}_{2} \mathrm{O}_{2}$ was correlated with the decreased capacity of peroxidases to scavenge $\mathrm{H}_{2} \mathrm{O}_{2}$, because of inhibition of the peroxidases by SHAM and $\mathrm{NaN}_{3}$ (Weinberger et al. 2005). From our results, we could infer that $\mathrm{H}_{2} \mathrm{O}_{2}$ in $S$. japonica was generated by a membrane-located NADPH oxidase, which was supported by transmission electron microscopy. By using the $\mathrm{Ce}-$ $\mathrm{H}_{2} \mathrm{O}_{2}$ electron staining technique, electron-dense deposits of cerium perhydroxide were observed in the plasma membranes (Fig. 8c-e) in female gametophytes challenged with flg22, which was similar to the results of $G$. conferta (Weinberger et al. 2005). Contrary to our results, in G. chilensis, $\mathrm{H}_{2} \mathrm{O}_{2}$ accumulation was inhibited by SHAM and $\mathrm{NaN}_{3}$ and was not affected by DPI with electron-dense deposits in cell walls instead of the plasma membranes (Weinberger et al. 2005). This may be caused by different mechanisms for the production of $\mathrm{H}_{2} \mathrm{O}_{2}$ between $S$. japonica and $G$. chilensis. We thus conclude that the source of $\mathrm{H}_{2} \mathrm{O}_{2}$ in female gametophytes of $S$. japonica is located in the plasma membranes.

In conclusion, our study showed that flg 15 is the smallest epitope of flagellin recognized by female gametophytes of $S$. japonica and that D43 at the N-terminus of the flagellin is essential for elicitor activity. The characteristic elicitor activities of flg22 and its derived peptides in the female gametophytes were similar to those described for tomato plants. This indicates that plants and algae share some very conservative features in elicitor recognition and subsequent defense reactions. This is surprising regarding the large phylogenetic distance between land plants and brown algae and considering the evolution of brown algae by secondary endosymbiosis and, thus, the involvement of a secondary host cell different to the primary host cell of land plants. The results of pharmacological investigations and of transmission electron microscopy revealed that the production of $\mathrm{H}_{2} \mathrm{O}_{2}$ induced by flg22 in $S$. japonica was related to NADPH oxidase-like enzymes, which are located on the plasma membranes. Our work here lays the foundation for future structure-function research on pathogen recognition by $S$. japonica, including the identification of flagellin/flg22 elicitor activity of pathogenic bacteria, elicitation-active site, and receptors.

Acknowledgments This study was sponsored by the National Natural Science Foundation of China (No. 41576158) granted to G.G. Wang; Science and Technology Development Project of Qingdao, China, 121 41 (4) jch; the Shandong Agriculture Breeding Engineering Biological Resources Innovation of Research Project; and Student Research Train ing Program (SRTP) of Ocean University of China (No. 201210423048).

\section{References}

Basse CW, Bock K, Boller T (1992) Elicitors and suppressors of the defense response in tomato cells Purification and characterization of glycopeptide elicitors and glycan suppressors generated by enzy matic cleavage of yeast invertase. J Biol Chem 267:10258 10265

Bauer Z, Gómez Gómez L, Boller T, Felix G (2001) Sensitivity of dif ferent ecotypes and mutants of Arabidopsis thaliana toward the bacterial elicitor flagellin correlates with the presence of receptor binding sites. J Biol Chem 276:45669 45676

Baureithel K, Felix G, Boller T (1994) Specific, high affinity binding of chitin fragments to tomato cells and membranes. J Biol Chem 269: 1793117938

Bestwick CS, Brown IR, Bennett MH, Mansfield JW (1997) Localization of hydrogen peroxide accumulation during the hypersensitive reac tion of lettuce cells to Pseudomonas syringae pv phaseolicola. Plant Cell 9:209 221

Boller T, Felix G (2009) A renaissance of elicitors: perception of microbe associated molecular patterns and danger signals by pattern recognition receptors. Annu Rev Plant Biol 60:379 406

Bouarab K, Potin P, Correa J, Kloareg B (1999) Sulfated oligosaccharides mediate the interaction between a marine red alga and its green algal pathogenic endophyte. Plant Cell 11:1635 1650

Canter HM, Jaworski GHM (1979) The occurrence of a hypersensitive reaction in the planktonic diatom Asterionella formosa Hassall par asitized by the chytrid Rhizophydium planktonicum Canter emend., in culture. New Phytol 82:187 206

Chinchilla D, Bauer Z, Regenass M, Boller T, Felix G (2006) The Arabidopsis receptor kinase FLS2 binds flg22 and determines the specificity of flagellin perception. Plant Cell 18:465 476

Cosse A, Leblanc C, Potin P (2007) Dynamic defense of marine macroalgae against pathogens: from early activated to gene regulated responses. Adv Bot Res 46:221 266

Felix G, Duran JD, Volko S, Boller T (1999) Plants have a sensitive perception system for the most conserved domain of bacterial fla gellin. Plant J 18:265 276 
Gómez Gómez L, Felix G, Boller T (1999) A single locus determines sensi tivity to bacterial flagellin in Arabidopsis thaliana. Plant J 18:277 284

Graham TL, Sequeira L, Huang TS (1977) Bacterial lipopolysaccharides as inducers of disease resistance in tobacco. Appl Environ Microb $34: 424432$

Jones DA, Takemoto D (2004) Plant innate immunity direct and indirect recognition of general and specific pathogen associated molecules. Curr Opin Immunol 16:48 62

Koller T, Bent AF (2014) FLS2 BAK1 extracellular domain interaction sites required for defense signaling activation. Plos One 9:e111185

Küpper FC, Gaquerel E, Boneberg EM, Morath S, Salaün JP, Potin P (2006) Early events in the perception of lipopolysaccharides in the brown alga Laminaria digitata include an oxidative burst and acti vation of fatty acid oxidation cascades. J Exp Bot 57:1991 1999

Küpper FC, Kloareg B, Guern J, Potin P (2001) Oligoguluronates elicit an oxidative burst in the brown algal kelp Laminaria digitata. Plant Physiol 125:278 291

Medzhitov R, Janeway CA (2002) Decoding the patterns of self and nonself by the innate immune system. Science 296:298 300

Meindl T, Boller T, Felix G (2000) The bacterial elicitor flagellin activates its receptor in tomato cells according to the address message con cept. Plant Cell 12:1783 1794

Meindl T, Boller T, Felix G (1998) The plant wound hormone systemin binds with the $\mathrm{N}$ terminal part to its receptor but needs the $\mathrm{C}$ terminal part to activate it. Plant Cell 10:1 11

Naito K, Taguchi F, Suzuki T, Inagaki Y, Toyoda K, Shiraishi T, Ichinose Y (2008) Amino acid sequence of bacterial microbe associated mo lecular pattern flg22 is required for virulence. Mol Plant Microbe Interact 21:1165 1174

Nürnberger T, Brunner F, Kemmerling B, Piater L (2004) Innate immu nity in plants and animals: striking similarities and obvious differ ences. Immunol Rev 198:249 266

Nürnberger T, Nennstiel D, Jabs T, Sacks WR, Hahlbrock K, Scheel D (1994) High affinity binding of a fungal oligopeptide elicitor to parsley plasma membranes triggers multiple defense responses. Cell 78:449 460

Paul C, Mausz MA, Pohnert G (2013) A co culturing/metabolomics ap proach to investigate chemically mediated interactions of planktonic organisms reveals influence of bacteria on diatom metabolism. Metabolomics 9:349 359

Potin P, Bourarab K, Salaun JP, Pohnert G, Kloareg B (2002) Biotic interactions of marine algae. Curr Opin Plant Biol 5:308 317
Sharp JK, McNeil M, Albersheim P (1984) The primary structure of one elicitor active and seven elicitor inactive hexa(beta D glucopyranosyl) D glucitols isolated from the mycelial walls of Phytophthora megasperma f. sp. glycinea. J Biol Chem 259:11321 11336

Song X, She X (2010) The generation and the role of hydrogen peroxide in plant. J Lianyungang Teachers College 4:99 103 (In Chinese with English abstract)

Sun W, Dunning FM, Pfund C, Weingarten R, Bent AF (2006) Within species flagellin polymorphism in Xanthomonas campestris pv campestris and its impact on elicitation of Arabidopsis FLAGELLIN SENSING2 dependent defenses. Plant Cell 18:764 779

Sun YD, Li L, Macho AP, Han ZF, Hu ZH, Zipfel C, Zhou JM, Chai J (2013) Structural basis for flg22 induced activation of the Arabidopsis FLS2 BAK1 immune complex. Science 342:624 628

Takai R, Isogai A, Takayama S, Che FS (2008) Analysis of flagellin perception mediated by flg22 receptor OsFLS2 in rice. Mol Plant Microbe Interact 21:1635 1642

Wang SS, Wei XJ, Lu BJ, Wang GG (2012) Preliminary study on flg22 induced defense responses in sporophytes of Saccharina japonica (Phaeophyta). J Fish China 36:1834 1841 (In Chinese with English abstract)

Wang SS, Zhao FY, Wei XJ, Lu BJ, Duan DL, Wang GG (2013) Preliminary study on flg22 induced defense response in female ga metophytes in Saccharina japonica (Phaeophyta). J Appl Phycol 25:1215 1223

Wei ZM, Laby RJ, Zumoff CH, Bauer DW, He SY, Collmer A, Beer SV (1992) Harpin, elicitor of the hypersensitive response produced by the plant pathogen Erwinia amylovora. Science 257:85 88

Weinberger F (2007) Pathogen induced defense and innate immunity in macroalgae. Biol Bull 213:290 302

Weinberger F, Friedlander M, Hoppe HG (1999) Oligoagars elicit a phys iological response in Gracilaria conferta (Rhodophyta). J Phycol $35: 747755$

Weinberger F, Friedlander M (2000) Response of Gracilaria conferta (Rhodophyta) to oligoagars results in defense against agar degrading epiphytes. J Phycol 36:1079 1086

Weinberger F, Leonardi P, Miravalles A, Correa JA, Lion U, Kloareg B, Potin P (2005) Dissection of two distinct defense related responses to agar oligosaccharides in Gracilaria chilensis (Rhodophyta) and Gracilaria conferta (Rhodophyta). J Phycol 41:863 873

Zipfel C (2009) Early molecular events in PAMP triggered immunity. Curr Opin Plant Biol 12:414 420 